\title{
Birkelundita, a new genus (Bivalvia, Carditacea) from the Upper Cretaceous white chalk of Europe
}

\author{
CLAUS HEINBERG
}

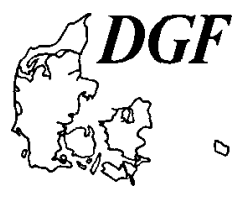

Heinberg, C.: Birkelundita, a new genus (Bivalvia, Carditacea) from the Upper Cretaceous of Europe. Bull. geol. Soc. Denmark, vol. 40, pp. 185-195. Copenhagen, June 3th, 1993. https://doi.org/10.37570/bgsd-1993-40-09

A new bivalve genus is described, based on a carditid species from the Upper Cretaceous white chalk of Europe. The possible evolutionary pathway through typical carditid morphological types to the new genus is analyzed in terms of adaptational strategies.

Claus Heinberg, Department of Environment, Technology and Social studies. Roskilde University Center, DK-4000 Roskilde, Denmark.

During an examination of the aragonitic bivalve fauna of the white chalk of Denmark (Heinberg 1976, 1979a, 1979b, 1989) a small carditid with a unique type of hinge was found. The species is designated genotype of the new genus Birkelundita of the family Carditidae.

The species is rare, but is found at various stratigraphical levels in the Upper Cretaceous white chalk of northern Europe. The known stratigraphical range is from the Turonian to the Upper Maastrichtian.

The peculiar hinge of the species, together with the remaining characteristics of the shell, has led to the reconstruction of the possible evolutionary pathway leading from an ancestral endobyssate carditid to Birkelundita. This reconstruction is not time specific, but is based on the possible adaptational derivation of the different, primarily Recent, known carditid morphotypes. The result is a pendulating evolutionary history with adaptational shifts from an infaunal mode of life to an epifaunal mode, and back again.

Family: CARDITIDAE Fleming, 1828

Genus: Birkelundita n.gen.

Genotype: Cardium turoniense Woods, 1897.

Locality and stratum: Chalk Rock of Cuckhamsley.

1897 Cardium turoniense Woods, p. 389, pl. XXVII, figs 20 22.

1987 "Begunia" turoniensis (Woods): Cleevely \& Morris p. 118 , pl. 15, figs 8,9 .

\section{Diagnosis}

Cordiform, inequilateral, obtuse, orbicular carditid. Anterior shell margin straight, anterodorsal shell corner prominent, supporting the anterior adductor. Hinge with extremely elongated hinge teeth (cardinals). Hinge of right valve with only one long lamellate tooth, left valve with two lamellate teeth. Ligament opisthodetic.

Umbo prominent, prosogyrate, overgrowing the lunula.

Sculpture of strong radiating ribs and grooves, crossed by relatively densely spaced, raised commarginal flanges forming tegulate spines where the ribs are crossed. The entire surface is covered by densely spaced minute thorns. Shell margin crenulated as is characteristic for carditids.

Anterior adductor scar prominent, posterior only visible in exceptional cases.

\section{Differential diagnosis}

The hinge of the genus has some similarity with other carditid genera with lamellate cardinals and "modioliform" anterior adductor, such as Cardita and Begunia, from which it is distinguished by the complete lack of other tooth elements than the lamellate ones. Both Cardita and Begunia have the cardinals $2 \mathrm{a}$ and $3 \mathrm{a}$, and in some species also laterals. The subcircular outline and the obtuse shape of the shell is clearly distinct from the flat 

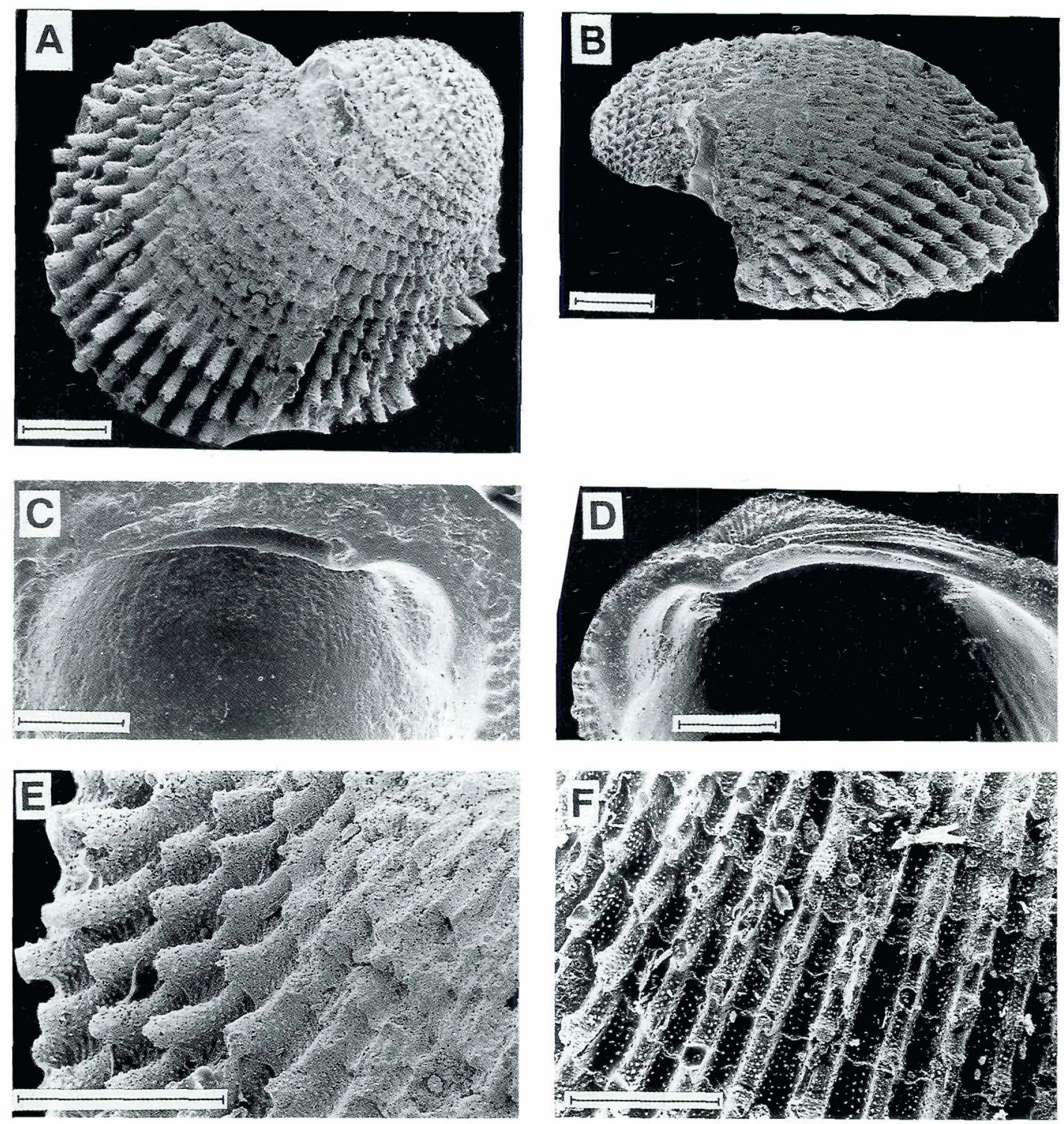

Fig. 1. Birkelundita turoniensis (Woods). Silicon rubber casts. A,B: Right valve seen in lateral view and posterier view. C.D: Inner surface of left and right valve showing hinge and anterior adductor scar. E, F: Detail of shell ornamentation. A, B,D, E,F: A specimen in the British Geological Survey, marked W2. C. MGUH 22071 from, Harmigny, Belgium (Campanian). Scale $1 \mathrm{~mm}$.

mytiliform shape of Begunia (fig. 6F) and the broad modioliform shape of Cardita (fig. 6C).

The position of the straight anterior shell margin is unique among subcircular carditids.

\section{Description}

The shell is of moderate size (max. height 8.8 $\mathrm{mm}$ ), obtuse, outline rounded subcircular, trun- cated anteriorly with a moderate modioliform 'spoon'-shaped projection supporting the anterior adductor, equivalve, inequilateral. Umbones prominent, projecting well above the hinge line, prosogyrate, overgrowing the lunula in much the same way as in the Recent Begunia. The ligament is opisthodetic.

The hinge of the right valve consists of two long parallel teeth, or tooth lamellae, separated by a long slender tooth socket (fig. 1D). 


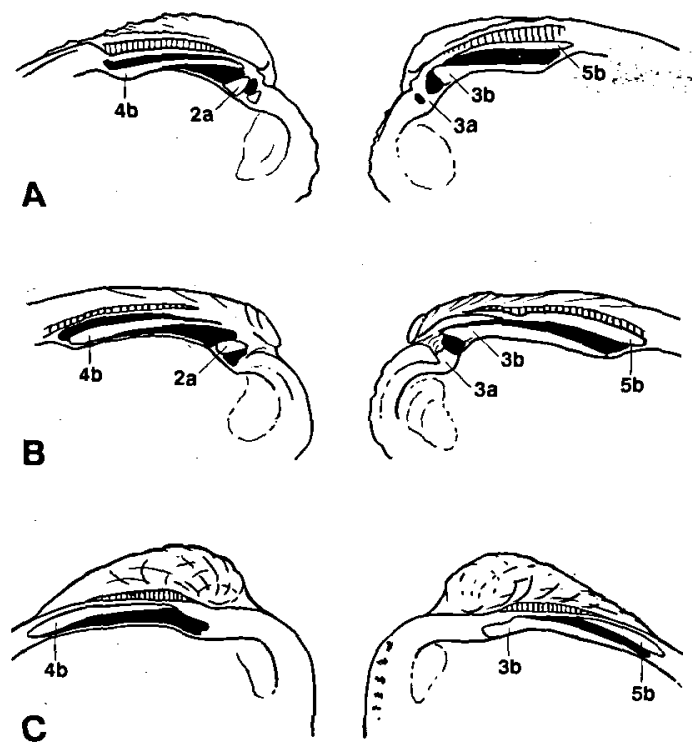

Fig. 2. Hinge formulae. A: Cardita variegata, B: Begunia semiorbiculata, C: Birkelundita turoniensis. Transverse striations: ligament. Not to scale.

The larger of the two teeth is extremely long and lamellate with fine transverse striations on its dorsal surface. The tooth is confluent with the ventral margin of the hinge plate. It has a blunt, slightly widened anterior part and tapers out posteriorly as it merges with the hinge plate.

The dorsal, somewhat shorter lamellate tooth is positioned parallel to the posterior half of the large ventral one. This tooth is rather uniform in width along its entire length, and has transverse striations on its ventral surface.

Correspondingly, the hinge of the left valve consists of one narrow tooth bounded ventrally by an "open" socket along the ventral margin of the hinge plate (fig. 1C). This socket is the counterpart to the larger ventral tooth of the right valve. Anteriorly the socket widenes into what may appear as a separate, but incipient, small tooth socket.

The only tooth of the left valve is long and slender, and bears fine transverse striations on either surface. The dorsal surface of the tooth is only sporadically known, and though the dorsal groove-shaped socket, corresponding to the dorsal tooth of the right valve, has been observed in several specimens, a well preserved example has not been found.

A knoblike projection on the hinge plate just anterior to the ventral socket, or sockets, may be interpreted as a rudimentary tooth.

The ornamentation consists of prominent radiating ribs separated by furrows of about equal width (fig. 1A,B,E,F). The ribs are crossed by rather densely spaced raised commarginal flanges forming prominent tegulate spines on the ribs, a typical "carditid" type of ornament. The entire outer surface, ribs, spines and furrows, is densely covered by minute thorns (fig. $5 \mathrm{~A}$ ).

The shell margin is crenulated with each crenulae corresponding to a radiating rib.

The anterior adductor is supported by a modioliform spoon-shaped extension of the anterodorsal shell corner (fig. 1D).

The rounded outline of the shell differs from that of other carditids of modioliform type having lamellate cardinals. These are invariably characterized by a rather extreme elongation of the shell in a postero-ventral direction.

Dimensions (max.): Height $8.8 \mathrm{~mm}$, length 8.7 $\mathrm{mm}$, width $8.8 \mathrm{~mm}$. Specimen MGUH 22070 from the Upper Maastrichtian of Stevns Klint. Derivation of name: Named after late professor Tove Birkelund, teacher and collegue.

\section{Material}

Upper Maastrichtian of Denmark (Stevns klint): 7 specimens

Lower Maastrichtian of Denmark (Møns klint): 1 specimen

Campanian of Belgium (Harmigny): 4 specimens Turonian of France (Beauval, Willeman, Dieppe): 3 specimens

Turonian of Britain (Dover): 1 specimen.

Occurrence according to the literature

Turonian, Chalk Rock of Berkshire, Oxfordshire, Hertfordshire and Kent (Cleevely \& Morris 1987). Chalk Rock of Cuckhamsley (Woods 1897).

\section{Interpretation of the hinge}

The hinge structure of Birkelundita is extremely reduced, more reduced than any other extant or fossil carditid species, and this fact together with 


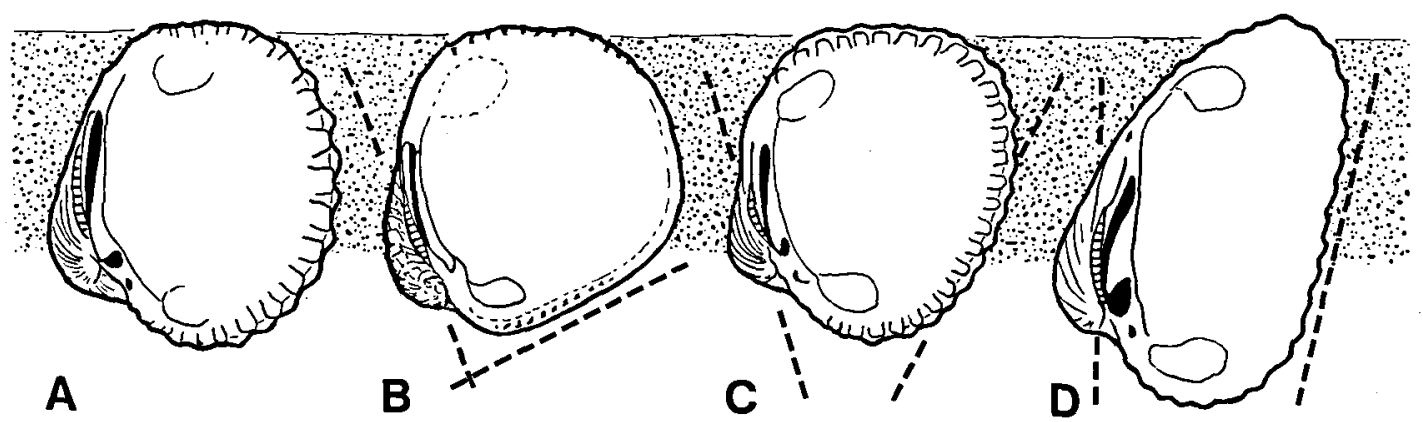

Fig. 3. Comparative morphology. The four carditid species constitute a morphological cline from a perfect rounded type of shell (A) to an elongated Arca-like type with a well developed "sole" (D), reflecting the shift from a completely free burrowing mode of life (A), to an endobyssate mode of life attached to a large substrate. Orientation of the "sole" and the hinge axes (indicated by broken lines) shows the transition from an almost right angle between the "sole" and the hinge axes (B), to a situation where the "sole" and the hinge axes are nearly parallel (D). A: Venericardia (Glyptoactis) nodifera, a free borrowing species. B: Birkelundita furoniensis, a free burrower. C: Venericardia (Claibornicardia) complexicostata, endobyssate species attached to multible small substrates in the sediment. D: Venericardia (Claibornicardia) nasuta, endobyssate species attached to a single large substrate. ' $A$ ', ' $\mathrm{C}$ ' and ' $\mathrm{D}$ ' modificd after Heaslip 1968. Not to scale.

the absence of early ontogenetic stages of Birkelundita which possibly could clarify the origin of the different hinge elements, permits a number of possible interpretations of the hinge.

The following interpretations are based on analogies with two Recent carditid species which exhibit hinges comparable to that of Birkelundita, i.e., Cardita variegata and Begunia semiorbiculata, as well as some fossil venericarditid species.

The Recent Cardita and Begunia species have relatively "advanced" carditid hinges, dominated by long, lamellate cardinals $(3 b, 4 b, 5 b)$ in association with transverse ones $(2 a, 3 a)$, following the interpretation of Yonge 1969 (fig. 2A,B). Lateral teeth are wanting or highly reduced.

In comparison, the hinge of Birkelundita is even more "advanced", and could be regarded as a type of "future carditid", were it not for its Upper Cretaceous age.

Following the simplest comparative interpretation of the Birkelundita hinge, the dentition of the right valve is composed of a $3 b$ cardinal (the large ventral lamella), a 4b' (the socket) and a $5 b$ cardinal (the dorsal lamella). Correspondingly, the left valve consists of a 3b' (the ventral socket), a $4 \mathrm{~b}$ cardinal (the lamellate tooth) and a $5 b$ ' (the dorsal socket), possibly with a reduced $2 \mathrm{a}$ (the small knoblike projection anterior to $3 \mathrm{~b}^{\text {') }}$ (fig. 2C).

This interpretation is the result of a direct "tooth to tooth" comparison between the fossil species and the two Recent ones, and it is re- garded as the most realistic. However, an alternative interpretation exists, which derives its justification from the evolutionary modifications of the hinge exhibited by some strands of alticostate venericards from the Tertiary of North America (Heaslip 1968).

The presence in Birkelundita of the possible 3a' socket posterior to the likewise dubious reduced cardinal $2 \mathrm{a}$, both in the left valve, could indicate that the ventral lamellate tooth of the right valve was actually the fused $3 a$ and $3 b$ cardinals (Heaslip personal communication).

This rather complicated situation, with $2 \mathrm{a}$ and $3 \mathrm{a}^{\prime}$ in reversed position, has an evolutionary analogy, though less extreme, among the Cenozoic alticostate venericards (Heaslip 1968). In a lineage ranging from Baluchicardia through Clairbornicardia to Glyptoactis, the $3 \mathrm{a}$ and the $3 \mathrm{~b}$ of the right valve are brought into alignment with each other through the "rotation" of $3 b$ around the central cardinal socket $\left(2 a^{\prime}\right) .3 b$ is brought to a position dorsal to the central cardinal $2 a$ (Heaslip 1968).

In Birkelundita, a similar process, if continued further, could have produced the actual hinge, with a completely fused $3 a$ and $3 b$, and the cardinal $2 a$ in the rotated position anterior to $3 b^{\prime}$. An unambiguous tooth socket ( $3 \mathrm{a}^{\prime}$ ) would have been a strong argument in favour of this possibility (Heaslip personal communication). This is not the case, and the first interpretation is accordingly preferred. 

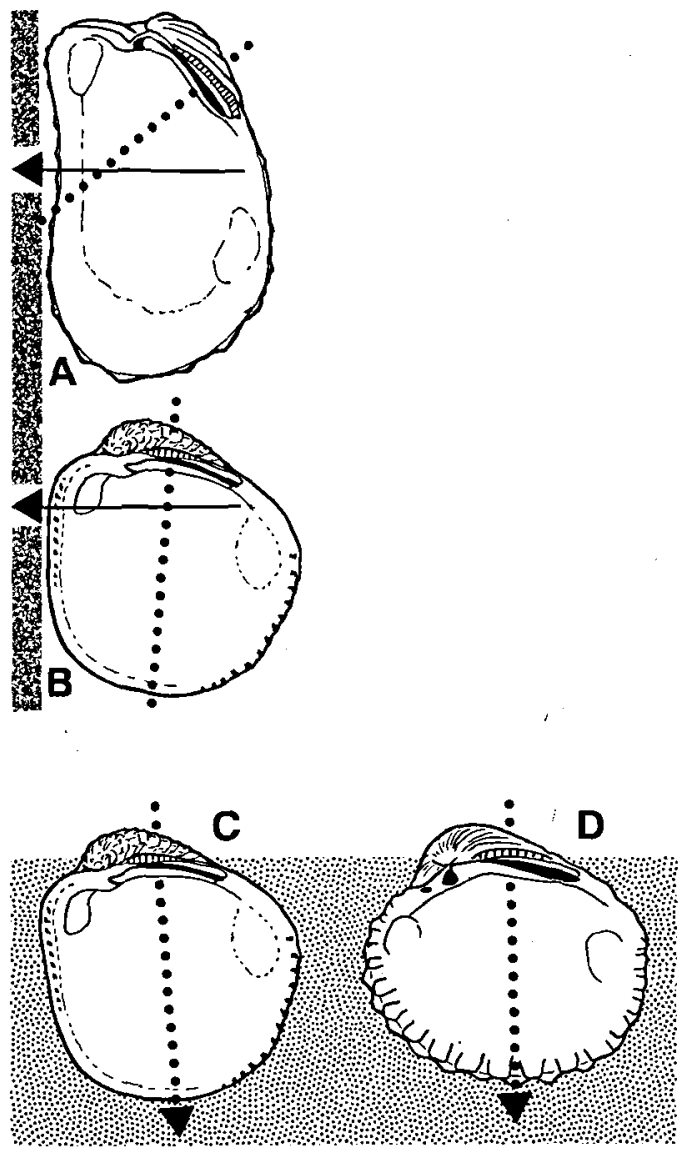

Fig. 4. Comparative functional morphology. B: Birkelundita, interpreted as an epibyssate form (due to the presence of the "sole"). Orientation of shell axes differs markedly from the situation in the typical epibyssate form A (Cardita variegata). C: Birkelundita interpreted as a burrowing form. Orientation of shell axes is identical to the situation in the typical free burrower D (Venericardia nodifera). Dotted line: the normal to the hinge axes through the middle of the ligament. Arrow: Byssus pulling vector (epibyssate) or position of foot emergense (burrowing). For discussion see text.

\section{Life habit and comparative shell morphology}

Birkelundita is a typical burrowing bivalve. Orbicular in shape, prominent prosogyrate umbones and with radial spiny ribs, it possesses the characteristics of a well fixed, sluggish and shallow burrowing bivalve (Stanley 1970). Viewed in more detail however, Birkelundita also possesses characters that are unusual for burrowing or endobyssate bivalves, as well as characters which, considered alone, could indicate an endo- or even an epibyssate mode of life.

These characters may become clearer when compared to a typical carditid burrower such as Venericardia (Glyptoactis) nodifera (fig. 3A). This Miocene species has an almost smoothly rounded outline, a shape found also among Recent freeburrowing carditids (e.g. Cardita ventricosa (fig. 6B)), as well as other free-burrowing bivalves.

In contrast, Birkelundita has a very distinct straight anterior shell margin (fig. 3B). Such a straight marginal sector is found in other Tertiary venericards, e.g. Venericardia (Claibornicardia) complexicostata (fig. 3C) and Venericardia (Claibornicardia) nasuta (fig. 3D); it is most extreme in the latter. The position, however, of the straight sector in the two differs from that of Birkelundita. In $V$.(C.) nasuta the straight part is almost parallel to the hinge axes, and in $V$.(C.). complexicostata the same two lines form an angle close to $45^{\circ}$. In Birkelundita the two lines form an almost right angle (fig. 3 ).

Interpreting the straight margin as a "sole" (a byssate character), Stanley (1972) regards $V .(C$. nasuta a byssate species, and the same may also be the case for $V .(C$.). complexicostata. Following this interpretation, $V .(C$.$) . nasuta exhibits an$ Arca-type modification, whereas $V .(C)$. complexicostata may be classified as a very moderate modioliform. The two species thus represent adaptations towards byssal fixation on a single large hard substrate or on multiple small scattered substrates respectively.

In either case, the vector of the combined byssus pull executed by the pedal retractor muscles will attack the middle of the sole at an right angle, which is the ideal position. Furthermore, a line perpendicular to the hinge axes from a position in the middle of the ligament, will intersect the commissure close to the point of byssus/foot emergence as reconstructed above.

The epibyssate Recent carditid Cardita variegata (fig. 4A), exhibits the same constructional arrangements with respect to the above mentioned axes as do the two endobyssate venericards (fig. 3C,D). The point of byssus emergence (and the byssal pulling vector) is positioned in the middle of the sole, and is confluent with the commissural point opposite the midpoint of the ligament.

This is certainly not the case in Birkelundita if the straight sector is interpreted as a functional sole. Following such an interpretation, the nor- 

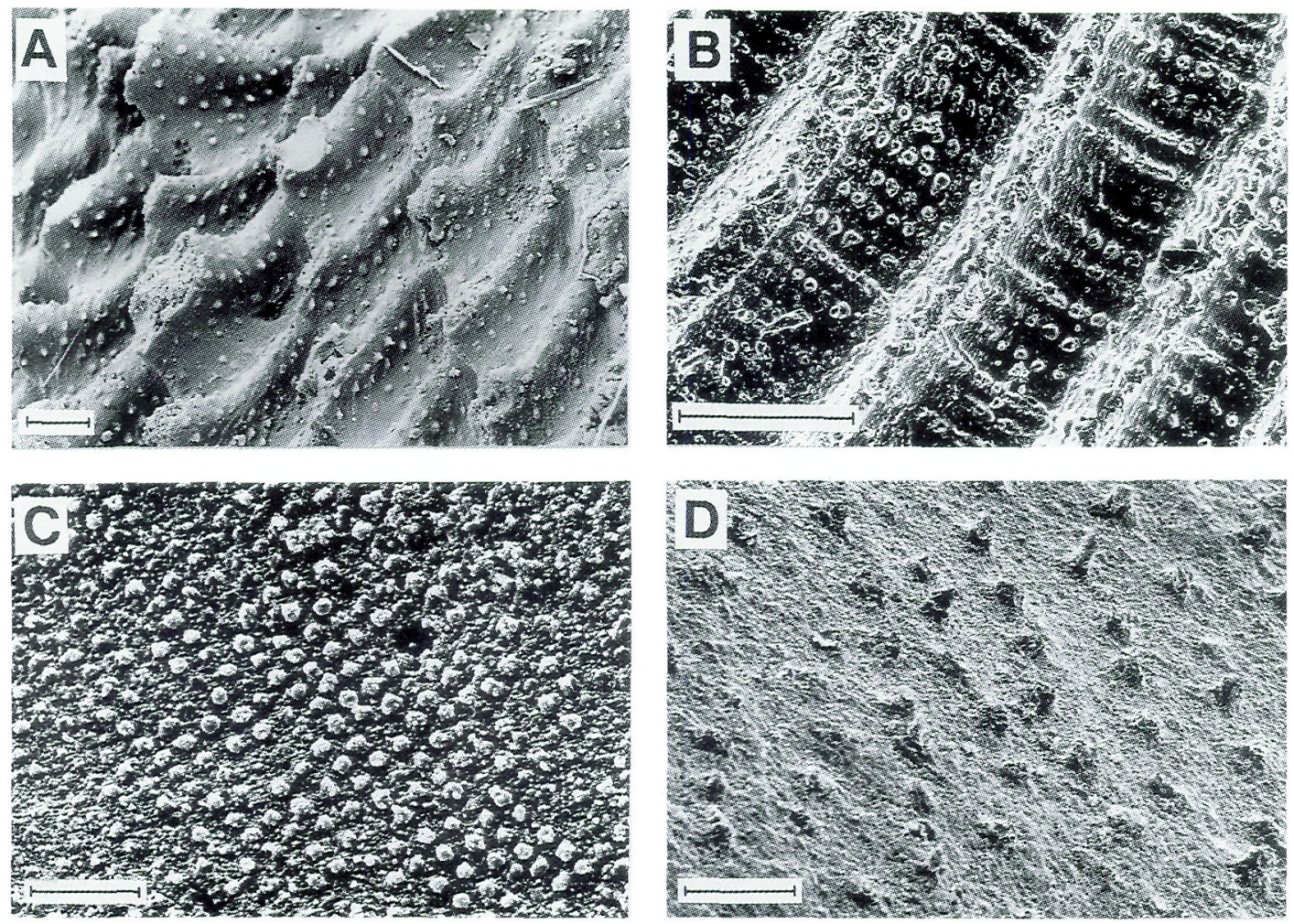

Fig. 5. Thorn ornamentation in different genera of white chalk bivalves. A: Birkelundita turoniensis, B: Vetericardiella sp., C: "Corbula" sp., D: Panopea sp. Scale: 1/10 mm.

mal to the straight sector through the attachment scar of the posterior pedal retractor (which is the pulling vector of the byssus) is extremely close to, or even in collision with, the anterior adductor, while the intersection point of the normal to the hinge axis is positioned on the ventral margin of the shell. The two axes are thus almost at right angles to each other.

This is a very inappropriate position for byssus emergence, and the straight part of the commissure is thus not regarded as a "sole", but rather a morphological "left over" from an epibyssate ancestor.

This argument is valid also against a possible epibyssate mode of life of Birkelundita (fig. 4B). Again the position of the posterior adductor, and consequently of the posterior pedal retractor, makes it unlikely that the straight part of the commissure could function as the sole of an epibyssally attached species, though a unique example of such a situation is found among the epibyssate species of Limopsis (Heinberg 1979).

Consequently, Birkelundita is interpreted as an infaunal burrower. This involves a reorientation of the foot relative to the epibyssate situation. Being a burrower, independent of a hard substrate, and thus the "sole", both pedal retractor muscles are equally involved in the burrowing action of the foot. The pulling vector will consequently intersect the shell margin at the point of maximum opening (point opposite the hinge axes) which is the normal position for foot emergence among burrowing bivalves (fig. 4C). The same arrangement of axes is found in the freeburrowing Venericardia (Glyptoactis) nodifera (fig. 4D).

The peculiar minute thorn ornament, covering the entire surface of the shell, is a character found in some other bivalve species from the white chalk; a Panopea, a corbulid and a Vetericardiella (fig. 5). These are all burrowing species of different genera, and the presence of minute thorns over such a wide range of bivalve taxa suggests that some specific property of the sediment is responsible for this special type of orna- 


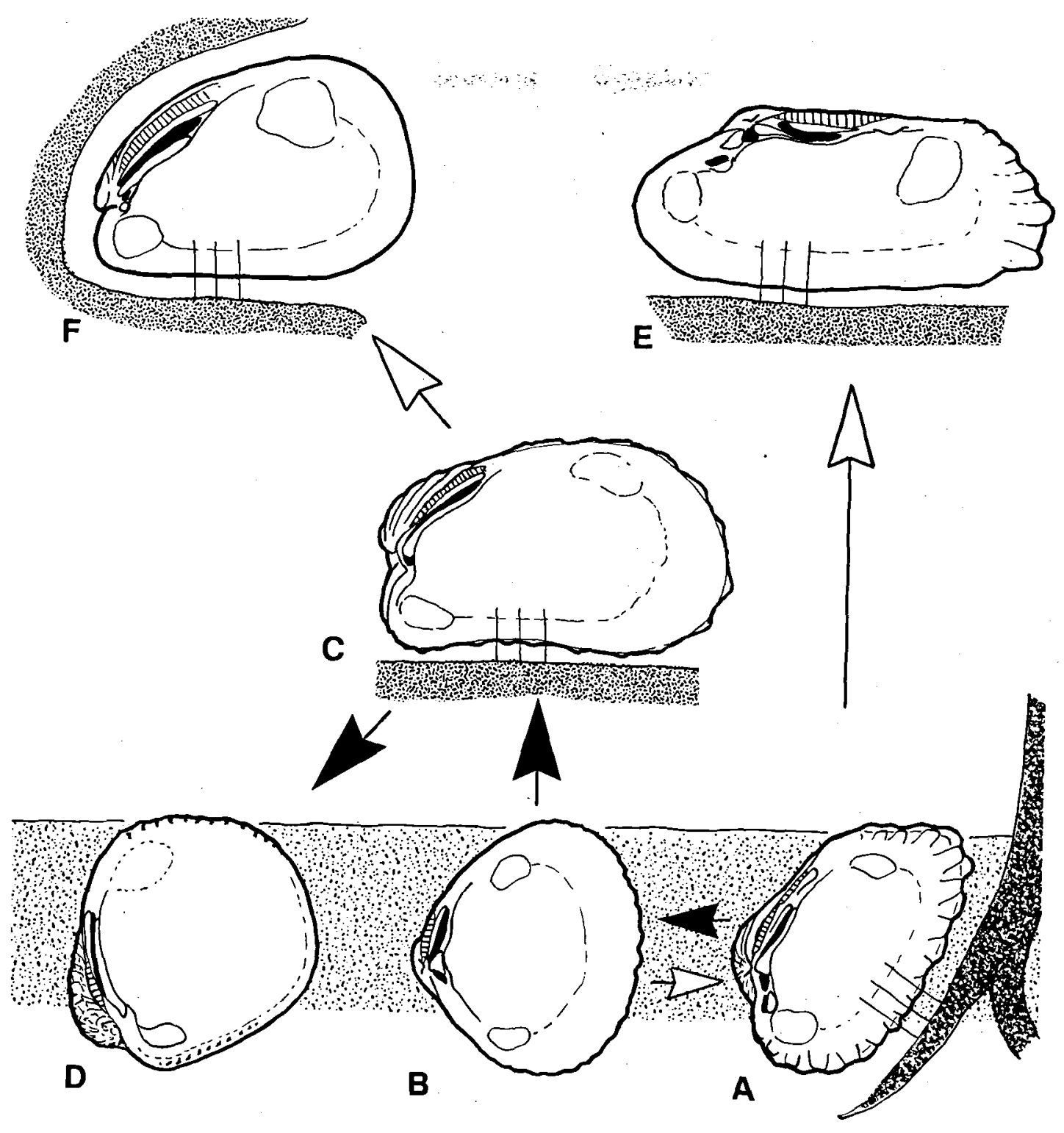

Fig. 6. Evolutionary morphology within the Carditacea. The diagram illustrates the possible evolutionary relationships among the different carditid morphotypes. Black arrows: evolutionary pathway from an Arca-type endobyssate carditid to Birkelundita. Black arrow between "A" and "B" according to Stanley 1972, white arrow following Younge 1969. Carditid morphotypes include endo- (A) and epibyssate (E) Arca-type forms. Modioliform (C) and Mytiliform (F) epibyssate forms, and two types of free burrowing forms (B \& D). Species typifying the different morphotypes: A: Cardita floridiana, B: Cardita ventricosa, C: Cardita variegata, D: Birkelundita turoniensis, E: Cardita affinis, F: Begunia semiorbiculata. For further discussion see text.

ment, a further argument for the burrowing mode of life in Birkelundita.

It is thus concluded that Birkelundita turoniensis is a shallow burrowing bivalve that enters its substrate in a "hinge up" position, and then after burial turns itself into a position (posterior up) where the siphonal apertures are in free contact with the water above the sediment/water interface. 


\section{Morphological radiation within the Carditacea}

A great portion of bivalve adaptive radiation can be related to one of two dominant life habits: the free-burrowing and the attached epibyssate, and the evolutionary shifts between the two. The course af evolution may go either way, but generally the presence of a byssus is considered a juvenile character, and free-burrowing the orignal adult mode of life.

The presence of byssus in the adult stage, a prerequesite for the evolution of epibyssate species, has subsequently been regarded a question of neoteny, and many bivalve families exhibit the characteristic morphological, and thereby evolutionary, dichotomy between subcircular freeburrowing forms and elongate epibyssate forms, often with endobyssate intermediate types. The Carditidae is an excellent example illustrating various aspects of this byssate/freeburrowing adaptational complex.

A number of basic morphotypes can describe the possible morphological routes from a freeburrowing subcircular bivalve, via an endobyssate stage to the epibyssate stage. By analogy, the stages may be termed as follows: The "Glycymeris" stage (free-burrowing), the "Modiolus" stage (endobyssate), and the "Mytilus", "Limopsis" and "Arca" stages respectively (all epibyssate) (Anthony 1905, Yonge 1953, Yonge 1969, Yonge \& Campbell 1968, Stanley 1972, Heinberg 1979 c).

In the "Arca" type, "byssification" is associated with antero-posterior elongation of the shell, producing the long straight ventral margin (the sole) essential for a stable contact with hard substrates. The two adductors remain of equal size through this process, and the ventral margin (the sole) and dorsal margin (hinge axes) are parallel with each other, and with a line passing through the centres of the two adductors.

In the case of "mytilization" and "modiolization", a marked reduction of the anterior part of the shell causes space problems. The reduction itself is a consequence of the necessary formation of a "sole", which in this case (mytilization/modiolization) forms an acute angle with the hinge axes, and with a line passing through the adductors.

This reduction results in either a strongly re- duced anterior adductor (mytilization), or the formation of a spoon-shaped anteroventral projection of the shell which can support a completely or almost unmodified anterior adductor (modiolization). A second, but important consequence of this is the transposition of the anterior adductor towards the umbo, which causes a reduction of the anterior part of the hinge.

It should be noted, that although the modioliform condition normally equates with the endobyssate mode of life, this is not the case among the Carditidae. Here, the typical modioliform species of Cardita are truely epibyssate, while the likewise modioliform Begunia semiorbiculata (fig. 6F) lives as a nestler among Porites corals.

The origination of subcircular free-burrowing carditids from endobyssate modioliform ancestors has been postulated by Stanley (1972) on stratigraphical grounds, whereas Yonge (1969) had the opposite view, that the free-burrowing type is the original.

Stanley suggested neoteny as the evolutionary mechanism, leading from the endobyssate Triassic Cardita crenata (Arcalike morphotype) via the Cretaceous Cardita tenuicostata (subcircular, burrowing) to the Recent Venericardia borealis (circular, free-burrowing). Another lineage is postulated from the Triassic Arca-like ancestor to the Recent likewise Arca-like Cardita floridana (endobyssate), a lineage which it seems obvious to continue into the Recent, extremely elongate Arca-type Cardita affinis (fig. 6E). This Arcatype lineage is characterized by a Venericardia type hinge with "normal" triangular cardinal teeth as well as laterals, and derivations from it. These derivations are primairly a question of anteroposterior stretching of the hinge. Another morphological trend eventually leading to Birkelundita passes through various byssiform stages of modiolization (and mytilization), involving the reduction of the lateral teeth (especially the anterior ones), the reduction of the anterior cardinals and the transformation of the posterior cardinals from a trianguler shape to lamellate, all important and necessary Birkelundita prerequisites.

\section{The adaptational origin of Birkelundita}

Hingewise, Birkelundita has all the characteristics of an epibyssate Cardita (or Begunia) associ- 
ated with large hard substrates. The hinge teeth are lamellate and parallel to the ligament, and the anterior part of the hinge is reduced. Other modioliform "fingerprints" are the sole-like straightening of the shell margin, and the position of the anterior adductor on the spoon-shaped anterodorsal extension of the shell. However, these characters, which are those of an epibyssate carditid, are in contradiction with the overall shape of the shell, exhibiting the characteristics of a typical free-burrowing bivalve.

With regard to the dental pattern, a rather conservative character relative to the general shape of the shell, this combination of contrasting features indicates that the burrowing Birkelundita is derived from a modioliform epibyssate species with a hinge much like the Recent Cardita (with Cardita variegata as an example).

The ancestral byssate stage thus is a necessary evolutionary prerequisite, simply because these characters are not correlatable to the burrowing mode of life, but must be regarded as inherited from an ancestral epibyssate stage. Following this procedure one problem remmains: the complete. reduction of the anterior hinge elements which are present in C. variegata.

\section{Pendulating evolution}

The morphological extrapolation of a Birkelundita type of bivalve, from what Stanley suggested is the ancestral carditid form, is a three step process (fig. 6).

First step is from an Arca-type endobyssate carditid to a free-burrowing form. Second step is the transition from the burrowing form to an epibyssate carditid through modiolization, and third step is the recolonization of the soft bottom by the evolution of a free burrower from the epibyssate form.

\section{The first step (fig. $6 A$ to $6 B$ )}

The transition from the endobyssate $A$ rca-type carditid (fig. 6A) to the free-burrowing carditid (fig. 6B) is an important precurser to the formation of the eventual Birkelundita-hinge. Only an equilateral free-burrowing type of bivalve will go through stages of modiolization in the evolutionary transition towards an epibyssate mode of life, and modiolization is necessary for the development of the characteristic Cardita-hinge, and sub- sequent Birkelunditahinge. The parallel trend from the endobyssate Arca-type ancestor will lead to a more extreme $A r c a$-type morphology as exemplified by the Recent Cardita affinis (fig. $6 \mathrm{E}$ ), and that trend will not lead to the formation of a Cardita/Birkelundita type of hinge.

Whether the Carditacea as a whole originated from a free-burrowing ancestor (Yonge 1969) or an $A r c a-$ like endobyssate form (Stanley 1972) is of no relevance in this context. Free-burrowing carditids were present during the Cretaceous.

\section{The second step (fig. $6 B$ to $6 \mathrm{C}$ )}

The formation of the characteristic lamellate hinge teeth is closely associated with the transition from the free-burrowing to the epibyssate modioliform mode of life. The Recent Cardita variegata (fig. 6C) is a typical example of such an epibyssate carditid. It is modioliform in outline and has a spoon-shaped anterodorsal projection supporting the anterior adductor. The concave ventral margin of the shell forms a broad "sole", owing to the considerable width of the shell, which is a typical epibyssate type of adaptation (Stanley 1970, Yonge \& Campbell 1968).

The shell thus possesses both modioliform (the anterior adductor, an endobyssate feature) and mytiliform (the sole, an epibyssate feature) elements. This combination, however, is characteristic for epibyssate carditids, where the anterior adductor seems to "resist" attempts of mytilization, to an extreme extent.

The hinge of Cardita variegata consists of long lamellate cardinals $(3 \mathrm{~b}, 4 \mathrm{~b}, 5 \mathrm{~b})$, very much like the situation in Birkelundita. A distinct triangular cardinal (2a) is present in the left valve, and this feature distinguishes the genus from Birkelundita.

The elongation of the posterior cardinals and slight reduction of the anterior ones in Cardita is the direct consequence of the byssate mode of life, caused by the posterior elongation and anterior reduction of the shell. As a further consequence, the lunula is brought into a position below the umbo.

\section{The third step (fig. $6 C$ to $6 D$ )}

The derivation of the Birkelundita-hinge from the modioliform Cardita-hinge, is exclusively a question of the further and eventually complete reduction of the anterior hinge elements, i.e., the 

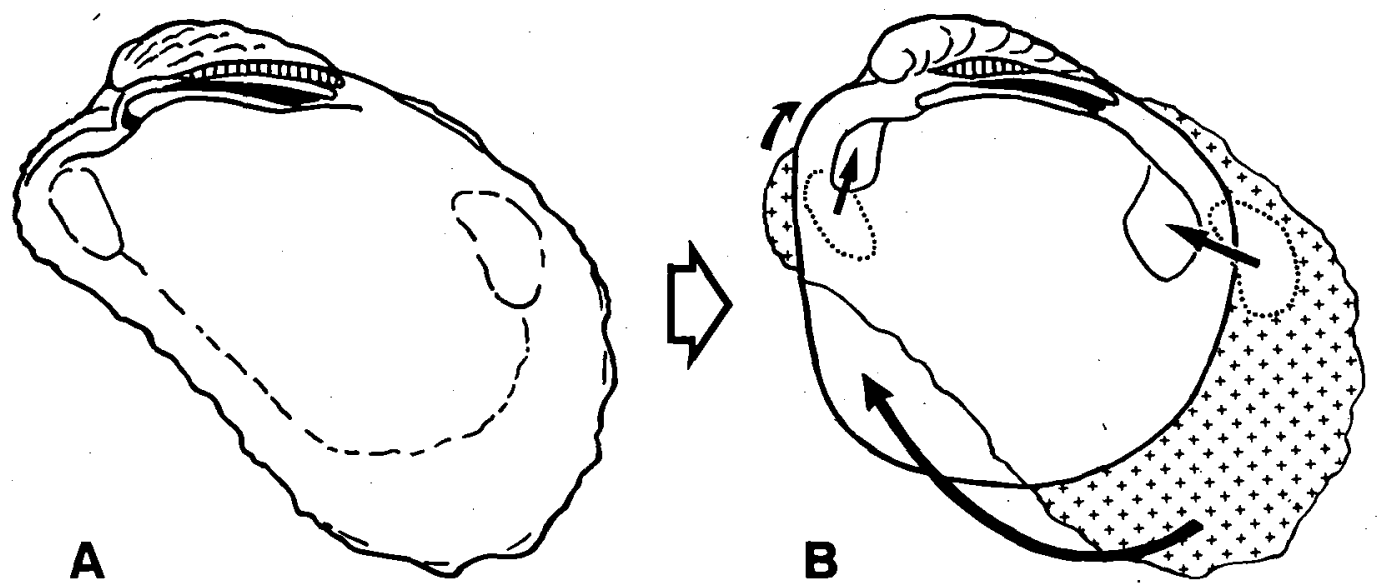

Fig. 7. The morphological transformation from a modioliform epibyssate carditid "A" (exemplified by Cardita variegata) to the burrowing Birkelundita "B", through clockwise torsion of the shell. The anterior hinge elements are reduced, and the lunula positoioned below the umbo. Black arrows: repositioning of shell elements following the transformation.

$2 a$ and $3 a$ cardinals. This reduction follows the morphological transformation from the epibyssate modioliform Cardita type of shell, to the obtuse, subcircular burrowing type represented by Birkelundita (fig. 6D). Such reduction is normally part of the modiolization process. In the present case it is associated with the reverse process; the transformation from an epibyssate modioliform type bivalve to the globose burrower.

Morphologically, this process has resulted from a clockwise (viewed from the left side) rotation of the posterior part of the Cardita variegata shell, accompanied by the anteroposterior shortening of the shell (fig. 7). This rotation, together with the shortening of the shell, forces the point of byssus emergence, present at intermediate stages, and the anterior adductor towards the umbo. Accordingly, the lunula "disappears" below the umbo in a manner similar to that found in Begunia semiorbiculata. In Birkelundita, however, the process proceeds further with the complete reduction of all anterior hinge elements as the final consequence.

The process of rotation is somewhat similar to that in the cardiacean genus Tridacna, which possesses a cardiacean hinge modified in very much the same way as in Birkelundita (Yonge 1936, Yonge 1953, Stasek 1961).

The adaptational shift from endofaunal to epifaunal mode of life and back again, is a parallel to the large scale evolutionary pattern in the arcoid phylogeny as demonstrated by Stanley (1972).
Acknowledgements. R. Bromley and Ulla Asgaard read the manuscript and offered helpfull criticism. Ritta Bitsch assisted in the preparation of the drawings.

\section{Dansk sammendrag}

En ny slægt af muslinger, Birkelundita, af familien Carditacea, opstilles på basis af fossilt materiale fra skrivekridtet. Slægten, representeret ved typearten Birkelundita turoniensis (Woods) er udbredt i det nordeuropaiske skrivekridt hvor den er fundet fra Turon til Øvre Maastrichtien.

Birkelundita der er en typisk gravende musling, er karakteriseret af et meget reduceret hængsel som ikke umiddelbart kan afledes af den gravende livsform. Ud fra hængselet, samt skallens øvrige karakterer, er der foretaget en adaptiv morfologisk rekonstruktion af slægtens mulige udviklingsmæssige historie. Resultatet er en art pendulerende evolution mellem gravende og epibyssat levevis. Et sådant evolutionært skifte mellem de to typer af levevis er nødvendigt, hvis de morfologiske karakteristika skal forklares. Fænomenet er kendt inden for andre grupper af muslinger.

\section{References}

Anthony, R. 1905: Influence de la fixation pleurothétique sur la morphologie des mollusques acéphales dimyaires. Ann. Sci. Nat. Zool. 9, 165-396.

Heaslip, W. G. 1968: Cenozoic evolution of the alticostate Venericards in the Gulf and East Coastal North America. Paleont. Amer. 6 (39), 55-135.

Heinberg, C. 1976: Bivalves from the white chalk (Maastrichtian) of Denmark: Limopsidae. Bull. geol. Soc. Denmark, $25,57-70$.

Heinberg, C. 1979 a: Bivalves from the white chalk (Maastrichtian) of Denmark, II: Arcoida. Bull. geol. Soc. Denmark $27,105-116$.

Heinberg, C. 1979 b: Bivalves from the white chalk (Maastrichtian) of Denmark, III: Cuspidariidae. Bull. geol. Soc. Denmark 28, 39-45. 
Heinberg, C. 1979 c: Evolutionary ecology of nine sympatric species of the pelecypod Limopsis in Cretaceous chalk. Lethaia 6, 325-340.

Heinberg, C. 1989: Biválves from the white chalk (Maastrichtian) of Denmark, IV: Nuculoida. Bull. geol. Soc. Denmark 37, 227-236.

Cleevely, R. J. \& Morris, N. J. 1987. Introduction to Mollusca and Bivalves, 73-191. In Smith, A. B.(ed.): Fossils of the Chalk. Palaeontological Association.

Stanley, S. M. 1970: Relation of Shell Form to Life Habits of the Bivalvia (Mollusca). Geological Society of America, Memoirs 125, $296 \mathrm{pp}$.

Stanley, S. M. 1972: Functional morphology and evolution of bysally attached bivalve molluscs. Journal of Paleontology $46,165-212$.

Stasek, C. R. 1961: The form, growth, and evolution of the Tridacnidae (giant clams): Archives de Zoologie expérimentaire et général 101, 1-40.
Woods, H. 1897: The Mollusca of the Chalk Rock: Part II. Quarterly Journal of the Geological Society 153, 377-406.

Woods, H, 1899-1913. A monograph of the Cretaceous Lamellibranchia of England. Palaeontolographical Society Monographs 1, 1-232; 2, 1-473.

Yonge, C. M. 1936: Mode of life, feeding, digestion, and symbiosis with zooxanthellae in the Tridacnidae. Great Barrier Reef Exp. 1928-1929, British Mus. Sci. Rept. 1, 283-321.

Yonge, C. M. 1953: The Monomyarian Condition in the Lamellibranchia. Transactions of the Royal Society of Edinburgh 62, 443-478.

Yonge, C. M. 1969: Functional Morphology and Evolution within the Carditacea (Bivalvia), Proceedings of the Malacological Society, London 38, 493-527.

Yonge, C. M. \& Campbell, J. I. 1968: On the Heteromyarian Condition in the Bivalvia with Special Reference to Dreissena polymorpha and Certain Mytilacea. Transactions of the Royal Society of Edinburgh 68 (2), 21-42. 